\title{
Evaluation of Antioxidant, Thrombolytic and Cytotoxic Potentials of Methanolic Extract of Aporosa wallichii Hook.f. Leaves: An Unexplored Phytomedicine
}

\author{
Shahana Sharmin ${ }^{1}$, Md. Tanvir Kabir ${ }^{*}$, Md. Nasiful Islam¹, Mohd. Raeed Jamiruddin ${ }^{1}$, Imon Rahman ${ }^{1}$, Arifur Rahman², \\ Mahboob Hossain ${ }^{3}$ \\ ${ }^{1}$ Department of Pharmacy, BRAC University, Dhaka, Bangladesh. \\ ${ }^{2}$ Department of Pharmacy, Jagannath University, Dhaka, Bangladesh. \\ ${ }^{3}$ Microbiology Program, Department of Mathematics and Natural Sciences, BRAC University, Dhaka, Bangladesh.
}

\section{ARTICLE INFO \\ Article history: \\ Received on: 11/04/2018 \\ Accepted on: 08/06/2018 \\ Available online: 30/07/2018}

Key words:

DPPH free radical

scavenging assay, Total

phenolic content, Brine

shrimp lethality assay,

Thrombolytic property, Cytotoxicity.

\begin{abstract}
Aporosa wallichii Hook.f. is a medicinal plant, which belongs to Phyllanthaceae family. This plant was used in this study for the determination of several pharmacological activities. This study involved experiments including determination of antioxidant property by performing 2,2-diphenyl-1-picrylhydrazyl (DPPH) free radical scavenging assay and total phenolic content (TPC) test, determination of cytotoxic activity by brine shrimp lethality assay and thrombolytic property analysis. In this study, it was observed that for DPPH free radical scavenging assay; standard (ascorbic acid) provided the $\mathrm{IC}_{50}$ value of $75.6 \mu \mathrm{g} / \mathrm{mL}$, whereas the extract provided the $\mathrm{IC}_{50}$ value of $58.7 \mu \mathrm{g} / \mathrm{mL}$. In case of TPC test, plant extract showed $308.97 \mathrm{mg}$ of gallic acid equivalents/g of extract. Brine shrimp lethality bioassay revealed the cytotoxic property of the plant and the $\mathrm{LC}_{50}$ value of the plant extract was $26.7 \mu \mathrm{g} / \mathrm{mL}$. Then again, the standard vincristine sulfate provided the $\mathrm{LC}_{50}$ value of $2.0 \mu \mathrm{g} / \mathrm{mL}$. Moreover, the thrombolytic analysis showed for standard (clopidogrel) $59.3 \%$ clot lysis and for extract $24.5 \%$ clot lysis. This study revealed that this plant has significant antioxidant activity, moderate level of cytotoxic activity and thrombolytic activity.
\end{abstract}

\section{INTRODUCTION}

The medicinal plants serve as a vital source of new pharmacologically active compounds (Atanasov et al., 2015). These agents are derived from different parts of plants and used directly as drug or as semi-synthesized or synthesized drug (Ghani, 2003). Origin of Aporosa wallichii Hook.f is dry evergreen forests of Meghalaya and Tripura in India, Bangladesh, Myanmar and Thailand (Schot, 2004). The local name of this plant is Kokra in Bangladesh and commonly known as Castoma (Hossain et al., 2015). The height of the tree can be up to $15 \mathrm{~m}$ and the diameter is about $15 \mathrm{~cm}$. It has thick, rough, grooved and brownish color bark. Plant's stipules are narrowly ovate and the size is about 5-7

"Corresponding Author

Md. Tanvir Kabir, Department of Pharmacy, BRAC University, Dhaka,

Bangladesh.E-mail:tanvir_kbr@yahoo.com $\mathrm{mm} \times 1.5-2.8 \mathrm{~mm}$. Leafstalk is cylindrical, smooth and size up to 6-19 $\mathrm{mm} \times 0.8-1.2 \mathrm{~mm}$. Leaves narrowly egg-shaped to narrowly elliptic and the size is up to $9-17.5 \mathrm{~cm} \times 3.5-6.5 \mathrm{~cm}$, the base is thick and small basal glands is black in color. The color of the upper part of the leaves is bright to yellowish green and color of lower part of the leaves is reddish green or brownish. Cuspidate of Aporosa wallichii Hook.f. is sharp, smooth, a little shiny and not fragile. On the surface of the plant's leaf, irregular dense dots are present. Fruits are smooth and ovoid. Young fruits are striped and the size is 9-11 $\mathrm{mm} \times 6-9 \mathrm{~mm}$ and the color is brown to black. Each fruit contains either 1 or 2 seeds (Schot, 2004). Aporosa wallichii Hook.f. is one of the plants of a Phyllanthaceae family. Different medicinal plants contain many therapeutic activities to treat cancer, skin diseases, inflammation, diarrhea, dysentery, jaundice and headache etc. (Rahman and Akter, 2013). A literature review of Aporosa wallichii Hook.f. plant showed that no significant previous study 
has been conducted on this plant (Fabricant and Farnsworth, 2001). However, previous studies on various species of Phyllanthaceae family showed powerful antioxidant, anthelmintic, antimicrobial, anti-diarrheal, anti-tumor, anti-inflammation and insecticidal properties (Li, 2000). Aporosa lindleyana is also from the same genus and has antioxidant, anti-amylase and lipid-lowering properties (Kathirgamanathar et al., 2018). This plant also has antimicrobial, analgesic (Srikrishna et al., 2008) and antidiuretic activity (Ganegamage et al., 2014). Other species like Baccaurea parviflora, Antidesma tomentosum, Aporosa aurea, and Mallotus paniculatus have various pharmacological properties including cytotoxicity and antitrypanosomal activity (Mohmod et al., 2015). Croton gratissimus also has an acceptable rate of antiplasmodial activity. On the other hand, Croton argyratus has excellent antiprotozoal activity (Abdullah et al., 2007). So, there is a high possibility of the presence of different types of pharmacological properties in Aporosa wallichii Hook.f. plant. Free radicals are responsible not only for aging but also for many age-related diseases (Harman, 2009). Evidence from various sources suggests that free radicals trigger cell death mechanisms in the body such as apoptosis and necrosis (Chatterjee et al., 2011). Blockage of veins is a thrombosis which affects different organs and this thrombosis can cause various pathological conditions (Bekker et al., 2009). Antithrombotic and thrombolytic therapies have a great effect on thrombosis and they play crucial roles in the management of thromboembolic disorders (Hirsh et al., 2008). Cytotoxic property is very important to destroy cancer cells. Therefore, this plant Aporosa wallichii Hook.f. can be a potential source of medicinal properties and for this purpose, this study was focused on to find out the antioxidant, cytotoxicity and thrombolytic activity of the plant.

\section{MATERIALS AND METHODS}

\section{Collection of plant materials}

The leaf part of Aporosa wallichii Hook.f. plant was collected in May 2017 from Moulovibazar district of Sylhet division; after that, it was sent to the National Herbarium Bangladesh (NHB), Mirpur, Dhaka for verification. It was authenticated by NHB and the plant accession number was also provided (DACB-44996).

\section{Preparation of the extract}

The leaves were washed with clean water to remove the plant scrap and dust particles. Then the cleaned leaves were allowed to dry under the sun for a day after which the leaves were dried for 1 hour at $30-40^{\circ} \mathrm{C}$ in a hot air oven. After that, the dry and crusty leaves were ground with coarse dust using a high capacity grinding machine. Approximately $900 \mathrm{~g}$ of powder was soaked in $2.5 \mathrm{~L}$ of methanol for a period of 2 days at a normal ambient temperature $\left(22-25^{\circ} \mathrm{C}\right)$ with occasional stirring. After that filtration was done by using a cotton filter (pore size: 110 $\mathrm{mm}$ ), then the maximum amount of solvent was evaporated by using rotary evaporator at $100 \mathrm{rpm}$ at $30^{\circ} \mathrm{C}$. Then the extract of the leaves was placed under laminar airflow cabinet to vaporize the solvent completely from the extract and it was used to avoid any possibility of microbial growth in the extract while drying. Finally, $22.4 \mathrm{~g}$ of plant leaf extract was obtained and it was kept in a dry and cool place with proper labeling. Antioxidant, brine shrimp lethality assay and thrombolytic studies were conducted with this extract.

\section{Chemicals}

The chemicals were gallic acid [Sigma-Aldrich, USA], sodium chloride [Sigma-Aldrich, USA], Folin-Ciocalteu reagent [Sigma-Aldrich, USA], vincristine sulphate [Sigma-Aldrich, USA], clopidogrel [Sigma-Aldrich, USA], 2,2-Diphenyl-1Picrylhydrazyl (DPPH) [Sigma-Aldrich, USA]., sodium carbonate [Merck, India] and ascorbic acid (ASA) [Merck, India], dimethyl sulfoxide (DMSO) [Fisher Scientific, UK]. All the chemicals used in this study were of analytical grade.

\section{Total phenolic content (TPC)}

Folin-Ciocalteu chemical easily oxidizes the phenols when these chemicals added in this ionic phenolic solution, the phenols easily oxidizes by reagents (Singleton et al., 1999). When the oxidation procedure completed in the solution yellow color of Folin-Ciocalteu chemical turned into dark blue. This color changed mixture measured in a $760 \mathrm{~nm}$ in UV spectrophotometer. Value of the absorbance plotted in the gallic acid calibration curve and data was evaluated as gallic acid equivalents (GAE) (Wolfe et al., 2003).

\section{DPPH free radical scavenging assay}

DPPH free radical scavenging assay was performed to determine the antioxidant activity of Aporosa wallichii. Methanol plant extracts showed free radical scavenging activities on stable 2,2-diphenyl-1-picrylhydrazyl radicals were measured for this test (Braca et al., 2001). At different concentrations, plant extracts were mixed with 2,2-diphenyl-1-picrylhydrazyl (DPPH) solution. In methanol or aqueous solution, it generated stable free radicals by the delocalization of the free electrons; which in turn produced a deep purple colored solution. Absorbance values of these concentrations were calculated at $517 \mathrm{~nm}$ in UV spectrometer and the decreasing value of DPPH at $517 \mathrm{~nm}$ is directly proportional to the radical scavenging activity (Brand-Williams et al., 1995).

Percentage of inhibition of DPPH free radical (I\%) was calculated by using the following equation:

$$
(\mathrm{I} \%)=((\text { Absorbance of blank }- \text { Absorbacne of sample }) /
$$
$($ Absorbance of blank $)) \times 100$

$50 \%$ of inhibition $\left(\mathrm{IC}_{50}\right)$ of extract concentration was calculated from the graph; where the percentage of inhibition (I\%) was plotted against extract concentration.

\section{Brine shrimp lethality assay}

Artemia salina shrimp used in this assay. Its offspring was hatched in replicated seawater to grow nauplii (Meyer et al., 1982). By adding the calculated amount of dimethylsulfoxide (DMSO), the sample was prepared in desired concentration by dilution. The nauplii were counted with visual examination and were placed in vials which contained around $5 \mathrm{~mL}$ simulated seawater. Subsequently, various concentrations of samples were added to the tubes by micropipette and vincristine sulfate was used as positive control. These tubes were then left in a dry place for 24 hours at room temperature. Finally, survivors were counted after 24 hours (Hossain et al., 2012). Percentage (\%) of mortality 
was calculated by using following equation:

Percentage $(\%)$ of mortality $=(($ Number of nauplii taken Number of nauplii alive $) /($ Number of nauplii taken $)) \times 100$

$50 \%$ of lethal concentration $\left(\mathrm{LC}_{50}\right)$ of extract concentration was calculated from the graph plotted percentage of mortality against concentration.

\section{Thrombolytic activity}

Thrombus hampers the normal flow of blood to cells and tissues by blocking the blood vessel which can lead to lack of blood and oxygen. So, thrombolytic medications such as urokinase, clopidogrel, and streptokinase remove this thrombus and help to keep cells and tissues in normal condition (Prasad et al., 2006). In this study, fresh human blood was collected and blood samples were taken in three different pre-weighed sterile microbes and allowed to incubate at $37^{\circ} \mathrm{C}$ for $45 \mathrm{~min}$. When the clot was formed, the upper fluid was entirely discharged from all micro-tube lines. Clopidogrel was used as positive control and water (distilled) was used as negative control. Each test tube was filled with $100 \mu \mathrm{l}$ of plant extract and then microtubes were incubated for $90 \mathrm{~min}$ at $37^{\circ} \mathrm{C}$. Afterward, the liquid was removed which was released from the clot and again the tubes were weighed to see the weight difference when the clot disruption occurred (Ali et al., 2014).

Percentage of clot lysis was calculated by the following equation:
$(\%)$ of clot lysis $=(($ released clot weight $) /($ clot weight after clot disruption) $) \times 100$.

\section{RESULTS AND DISCUSSION}

\section{Antioxidant property}

In this experiment, methanol extract of Aporosa wallichii Hook.f. leaves were tested properly through DPPH assay and TPC to determine the antioxidant property of this plant (Pavithra et al., 2009). Antioxidant activity is very important in preventing free radical reactions because they can neutralize free radical by their reducing ability.

\section{Determination of DPPH radical scavenging activity}

Here, the percentage of inhibition of ascorbic acid and methanol extract in different concentrations were obtained (Table 1). It was found that DPPH free radical scavenging activity was increasing along with increasing concentration of the methanol extract (Figure 1). As the reference standard, ascorbic acid was used in this experiment for which $\mathrm{IC}_{50}$ value was $75.6 \mu \mathrm{g} / \mathrm{mL}$. On the other hand, the $\mathrm{IC}_{50}$ value of the methanol extract of Aporosa wallichii Hook.f. leaves were $58.7 \mu \mathrm{g} / \mathrm{mL}$ (Table 1). This result indicates the presence of DPPH free radical scavenging activity; which specifies the presence of antioxidant activity in Aporosa wallichii Hook.f.

Table 1: Evaluation of DPPH free radical scavenging activity of methanol extract of Aporosa wallichii Hook.f. leaves.

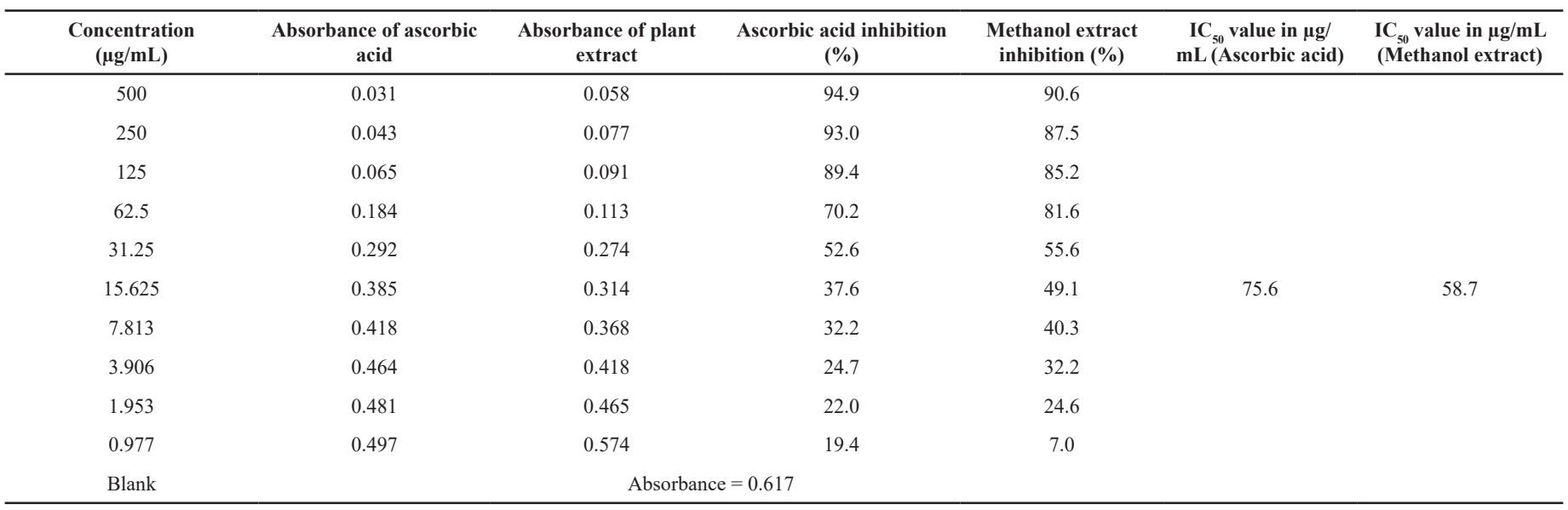

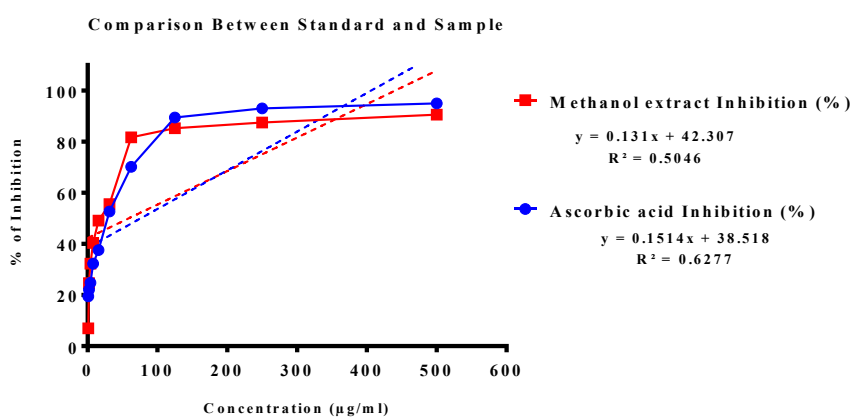

Fig. 1: Comparison of \% inhibition between ascorbic acid and methanol extract.

\section{Total phenolic content (TPC)}

In total phenolic content test methanol extract showed a significant level of reducing power. In this test, the gallic acid used as standard and methanol extract's absorbance plotted in gallic acid calibration curve (Figure 2). The absorbance of the plant extract was high for that reason the obtained TPC value was $308.97 \mathrm{mg}$ of GAE/g of extract (Table 2). This TPC value indicated that Aporosa wallichii Hook.f. has antioxidant activity.

\section{Cytotoxic property}

Brine shrimp lethality assay

The brine shrimp lethality assay was used to assess the cytotoxic property of methanol extract (Runa et al., 2013). At 
different concentrations; standard and extract provided different percentages of mortality (Table 3). Vincristine sulfate was used in this experiment as a standard (positive control), in which $2.0 \mu \mathrm{g} / \mathrm{mL}$ was obtained as the value of $\mathrm{LC}_{50}$, compared to the standard methanol extract of the Aporosa wallichii Hook.f. leaves gave $26.7 \mu \mathrm{g} / \mathrm{mL}$ as the value of $\mathrm{LC}_{50}$ (Table 3). Percentage of mortality was found to increase with increasing concentrations of vincristine sulfate and methanol extract (Figures 3 and 4). This study indicated the methanol extract of Aporosa wallichii Hook.f. leaves have cytotoxic activity.

Table 2: Total phenolic content (TPC) profile of the plant extract of Aporosa wallichii Hook.f. leaves.

\begin{tabular}{cccc}
\hline $\begin{array}{c}\text { Name of } \\
\text { extract }\end{array}$ & Plant part & $\begin{array}{c}\text { The absorbance of } \\
\text { methanol plant extract }\end{array}$ & $\begin{array}{c}\text { Total phenolic content } \\
\text { (mg of GAE/g of extract) }\end{array}$ \\
\hline $\begin{array}{c}\text { Methanol } \\
\text { extract }\end{array}$ & $\begin{array}{c}\text { Leaves of } \\
\text { Aporosa wallichii }\end{array}$ & 2.5 & 308.97 \\
\hline
\end{tabular}

Table 3: Brine shrimp lethality profile of the plant extract of Aporosa wallichii Hook.f. leaves.

\begin{tabular}{|c|c|c|c|c|c|}
\hline $\begin{array}{c}\text { Concentration } \\
(\mu \mathrm{g} / \mathrm{mL})\end{array}$ & $\begin{array}{c}\% \text { of Mortality } \\
\text { (Vincristine sulphate) }\end{array}$ & $\begin{array}{c}\mathrm{LC}_{50} \mu \mathrm{g} / \mathrm{mL} \\
\text { (Vincristine sulphate) }\end{array}$ & $\begin{array}{c}\text { Concentration } \\
(\mu \mathrm{g} / \mathrm{mL})\end{array}$ & $\begin{array}{c}\% \text { of Mortality } \\
\text { (Methanol extract of leaves) }\end{array}$ & $\begin{array}{c}\mathrm{LC}_{50} \mu \mathrm{g} / \mathrm{mL} \\
\text { (Methanol extract of leaves) }\end{array}$ \\
\hline 0.039 & 20 & \multirow{10}{*}{2.0} & 0.781 & 20 & \multirow{10}{*}{26.7} \\
\hline 0.078 & 30 & & 1.562 & 20 & \\
\hline 0.156 & 30 & & 3.125 & 30 & \\
\hline 0.312 & 40 & & 6.25 & 50 & \\
\hline 0.625 & 50 & & 12.5 & 60 & \\
\hline 1.25 & 60 & & 25 & 70 & \\
\hline 2.5 & 70 & & 50 & 70 & \\
\hline 5 & 80 & & 100 & 80 & \\
\hline 10 & 90 & & 200 & 90 & \\
\hline 20 & 100 & & 400 & 100 & \\
\hline
\end{tabular}

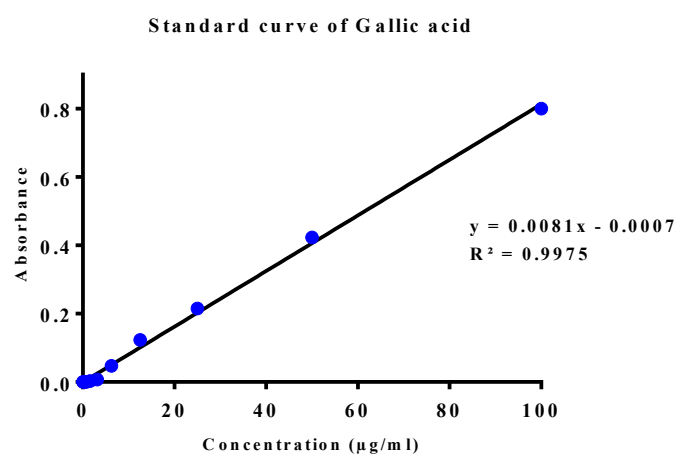

Fig. 2: Gallic acid's standard curve for the total phenolic content test.

Effects of Vincristine Sulfate on naplii

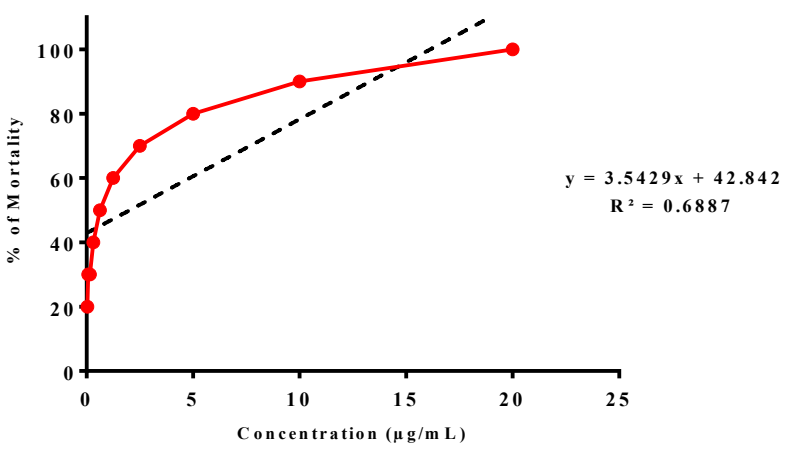

Fig. 3: Percentage (\%) of mortality and predicted regression line of vincristine sulfate.

\section{Thrombolytic activity}

Plasminogen enzyme is usually activated by thrombolytic agents and it also removes fibrin bonds in blood, as a result, the clot becomes soluble and blood flow is restored. Here, methanol extract showed much lower level of thrombolytic activity than standard (Figure 5). In thrombolytic activity test, clopidogrel was used as a positive control; because it is a blood thinning agent (Maegdefessel et al., 2010). Clopidogrel gave $59.3 \%$ clot lysis, distilled water was used as a negative control, which provided $2.5 \%$ clot lysis and methanol extract of Aporosa wallichii Hook.f. leaves showed $24.5 \%$ clot lysis (Table 4). After comparing the clots lysis value of plant extract with the positive control value, it was observed that Aporosa wallichii Hook.f. revealed thrombolytic activity.

Table 4: Evaluation and results of the thrombolytic activity.

\begin{tabular}{ccccccc}
\hline Name of samples & W1 & W2 & W3 & W4 & W5 & $\begin{array}{c}\text { \% of clot } \\
\text { lysis }\end{array}$ \\
\hline Plant extract & 0.789 & 1.547 & 1.398 & 0.609 & 0.149 & 24.5 \\
$\begin{array}{c}\text { Clopidogrel } \\
\text { (Anti-platelet agent) } \\
\text { as standard } \\
\text { Blank }\end{array}$ & 0.799 & 1.559 & 1.276 & 0.477 & 0.283 & 59.3 \\
\hline
\end{tabular}

Here, W1 = Micro-tube weight, W2 = Clot with micro-tube weight, W3 = Clot with micro-tube weight after clot disruption, W4 = Clot weight after clot disruption, W5 = Released clot weight.

\section{CONCLUSION}

The methanol extract of the Aporosa wallichii Hook.f. leaf was investigated to evaluate the therapeutic properties. In this study, it was clearly observed that Aporosa wallichii Hook.f. has various therapeutic potentials. This study showed that this plant has an acceptable level of antioxidant and thrombolytic property along with the moderate level of the cytotoxic property. Furthermore, additional investigations on Aporosa wallichii Hook.f. to find out 
unidentified biological properties; will help in the development of new and effective therapeutic agent in the field of medicine.

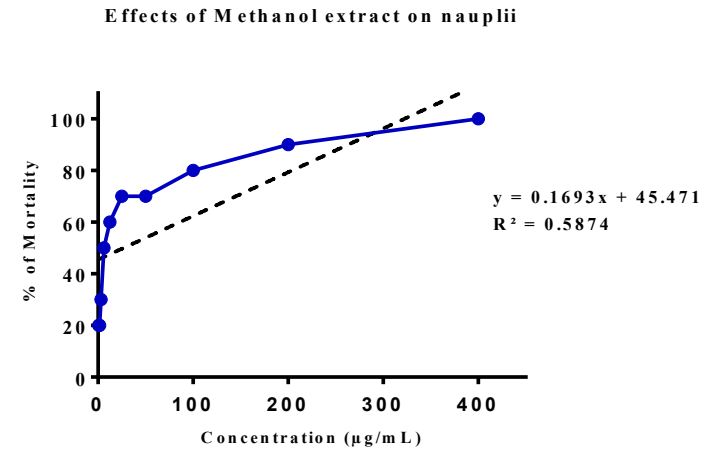

Fig. 4: Percentage (\%) of mortality and predicted regression line of methanol extract of Aporosa wallichii Hook.f.

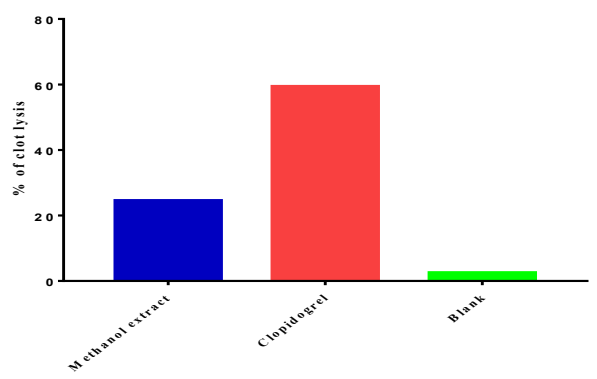

Fig. 5: Percentage (\%) of clot lysis of sample, standard, and blank.

\section{CONFLICT OF INTERESTS} interest.

The authors proclaim that they have no conflicts of

\section{ABBREVIATIONS}

$\begin{array}{ll}\text { ASA } & \text { Ascorbic acid } \\ \text { DMSO } & \text { Dimethyl sulfoxide } \\ \text { DPPH } & \text { 2,2-diphenyl-1-picrylhydrazyl } \\ \text { NHB } & \text { National herbarium Bangladesh } \\ \text { TPC } & \text { Total phenolic content } \\ \text { DMSO } & \text { Dimethylsulfoxide } \\ \text { GAE } & \text { Gallic acid equivalents }\end{array}$

\section{REFERENCES}

Abdullah NR, Khozirah S, Ridzuan Md. MA, Ong BK, Rohaya C, Rosilawati M, Hamdina I, Badrul A, Zakiah I. Antiplasmodial properties of some Malaysian medicinal plants. Trop Biomed, 2007; 24(1):29-35.

Ali R, Hossain M, Runa JF, Hasanuzzaman M, Islam M. Evaluation of thrombolytic potential of three medicinal plants available in Bangladesh, as a potent source of thrombolytic compounds. Avicenna Journal of Phytomedicine, 2014; 4(6):430-436.

Atanasov AG, Waltenberger B, Pferschy-Wenzig E-M, Linder T, Wawrosch C, Uhrin P, Temml V, Wang L, Schwaiger S, Heiss EH, Rollinger JM, Schuster D, Breuss JM, Bochkov V, Mihovilovic MD, Kopp B, Bauer R, Dirsch VM, Stuppnerb H. Discovery and resupply of pharmacologically active plant-derived natural products: A review. Biotechnology advances,
2015; 33(8):1582-1614.

Bekker J, Ploem S, Jong KP. Early Hepatic Artery Thrombosis after Liver Transplantation: A Systematic Review of the Incidence, Outcome and Risk Factors. American Journal of Transplantation, 2009; 9(4):746-757.

Braca A, Tommasi ND, Bari LD, Pizza C, Politi M, Morelli I. Antioxidant Principles from Bauhinia Terapotensis. Journal of Natural Products, 2001; 64:892-895.

Brand-Williams W, Cuvelier M, Berset C. Use of a free radical method to evaluate antioxidant activity. LWT - Food Science and Technology, 1995; 28(1):25-30.

Chatterjee S, Lardinois O, Bhattacharjee S, Tucker J, Corbett J, Deterding L, Mason RP. Oxidative stress induces protein and DNA radical formation in follicular dendritic cells (FDCs) of the germinal center and modulates its cell death patterns in late sepsis. Free Radical Biology \& Medicine, 2011; 50(8):988-999.

Fabricant DS, Farnsworth NR. The value of plants used in traditional medicine for drug discovery. Environmental Health Perspectives, 2001; 109(Suppl 1):69-75.

Ganegamage S, Abeytunga Y, Ratnasooriya W. Antidiuretic Activity of the Methanol Extract of Aporusa lindleyana Wight (Euphorbiacea) Baillon in Rats. Tropical Journal of Pharmaceutical Research, 2014; 13(7):1099.

Ghani A. 2003. Medicinal Plants of Bangladesh. Dhaka, Bangladesh: The Asiatic.

Harman D. About "Origin and evolution of the free radical theory of aging: A brief personal history, 1954-2009". Biogerontology, 2009; 10(6):783-783.

Hirsh J, Guyatt G, Albers GW, Harrington R, Schünemann HJ Antithrombotic and Thrombolytic Therapy: American College of Chest Physicians Evidence-Based Clinical Practice Guidelines (8th Edition). Chest, 2008; 133(6):110S-112S.

Hossain MA, Hossain MK, Alam MS, Uddin MM. Composition and Diversity of Tree Species in Kamalachari Natural Forest of Chittagong South Forest Division, Bangladesh. Journal of Forest and Environmental Science, 2015; 31(3):192-201.

Hossain S, Kader G, Nikkon F, Yeasmin T. Cytotoxicity of the rhizome of medicinal plants. Asian Pacific Journal of Tropical Biomedicine, 2012; 2(2):125-127.

Kathirgamanathar S, Abeysekera WP, Weerasinghe DM, Ranasinghe P, Binduhewa AM. Antioxidant, anti-amylase and lipid lowering potential of leaves of Aporosa lindleyana Baill. (Kebella). Sri Lankan Journal of Biology, 2018; 3(1):1.

Li L. Opportunity and Challenge of Traditional Chinese Medicine in Face of the Entrance to WTO (World Trade Organization). 2000; 7:7-8, http://www.scirp.org/(S(lz5mqp453edsnp55rrgjct55))/ reference/ReferencesPapers.aspx?ReferenceID=1564955.

Maegdefessel L, Azuma J, Tsao PS. Modern role for clopidogrel in management of atrial fibrillation and stroke reduction. Vascular Health and Risk Management, 2010; 6:95-103.

Meyer BN, Ferrigni NR, Putnam JE, Jacobsen LB, Nichols DE, Mclaughlin JL. Brine Shrimp: A Convenient General Bioassay for Active Plant Constituents. Planta Med, 1982; 45(5):31-34.

Mohmod AL, Krishnasamy G, Adenan MI. Malaysian plants with potential in vitro trypanocidal activity. Annals of Phytomedicine, 2015; 4(1):6-16.

Pavithra PS, Srevidya N, Verma RS. Antibacterial and antioxidant activity of methanol extract of Evolvulus nummularius. Indian J Pharmacology, 2009; 41:233-236.

Prasad S, Kashyap RS, Deopujari JY, Purohit HJ, Taori GM, Daginawala HF. Development of an in vitro model to study clot lysis activity of thrombolytic drugs. Thrombosis Journal, 2006; 4:14.

Rahman AHMM, Akter M. Taxonomy and Medicinal Uses of Euphorbiaceae (Spurge) Family of Rajshahi, Bangladesh. Research in Plant Sciences, 2013; 1(3):74-80.

Runa JF, Hossain M, Hasanuzzaman M, Ali MR. Investigation 
of Phenolic Profiles, Cytotoxic Potential and Phytochemical Screening of Different Extracts of Drynaria quercifolia J. Smith (Leaves). Advanced Pharmaceutical Bulletin, 2013; 3(2):465-467.

Schot AM. Systematics of Aporosa (Euphorbiaceae). Brittonia, 2004; 57:202-203.

Singleton VR, Orthifer R, Lamuela-Raventos RM. Analysis of total phenols and other oxidation substrates and antioxidants by means of Folin-Ciocalteu reagent. Methods Enzymol, 1999; 299:152-178.

Srikrishna LP, Vagdevi HM, Basavaraja BM, Vaidya VP. Evaluation of antimicrobial and analgesic activities of Aporosa lindleyana (Euphorbiaceae) bark extract. International Journal of Green Pharmacy, 2008; 2(3):155.
Wolfe K, Wu X, Liu RH. Antioxidant Activity of Apple Peels Journal of Agricultural and Food Chemistry, 2003; 51(3):609-614.

\section{How to cite this article:}

Sharmin S, Kabir MT, Islam MN, Jamiruddin MR, Rahman I, Rahman A, Hossain M. Evaluation of Antioxidant, Thrombolytic and Cytotoxic Potentials of Methanolic Extract of Aporosa wallichii Hook.f. Leaves: An Unexplored Phytomedicine. J App Pharm Sci, 2018; 8(07): 051-056. 